\title{
Perinatal factors and hearing outcome
}

\author{
Citation for published version (APA):
}

Smits, A. L. (2017). Perinatal factors and hearing outcome. [Doctoral Thesis, Maastricht University]. Maastricht University. https://doi.org/10.26481/dis.20170112als

Document status and date:

Published: 01/01/2017

DOI:

10.26481/dis.20170112als

Document Version:

Publisher's PDF, also known as Version of record

Document license:

Unspecified

\section{Please check the document version of this publication:}

- A submitted manuscript is the version of the article upon submission and before peer-review. There can be important differences between the submitted version and the official published version of record.

People interested in the research are advised to contact the author for the final version of the publication, or visit the DOI to the publisher's website.

- The final author version and the galley proof are versions of the publication after peer review.

- The final published version features the final layout of the paper including the volume, issue and page numbers.

Link to publication

\footnotetext{
General rights rights.

- You may freely distribute the URL identifying the publication in the public portal. please follow below link for the End User Agreement:

www.umlib.nl/taverne-license

Take down policy

If you believe that this document breaches copyright please contact us at:

repository@maastrichtuniversity.nl

providing details and we will investigate your claim.
}

Copyright and moral rights for the publications made accessible in the public portal are retained by the authors and/or other copyright owners and it is a condition of accessing publications that users recognise and abide by the legal requirements associated with these

- Users may download and print one copy of any publication from the public portal for the purpose of private study or research.

- You may not further distribute the material or use it for any profit-making activity or commercial gain

If the publication is distributed under the terms of Article $25 \mathrm{fa}$ of the Dutch Copyright Act, indicated by the "Taverne" license above, 
I

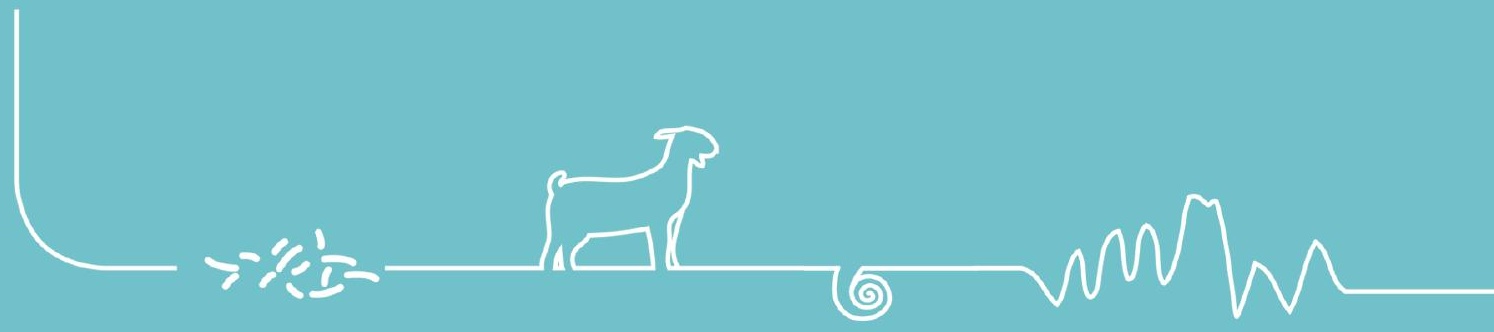

Summary 



\section{Summary}

The studies included in this thesis address a number of topics concerning perinatal risk factors in relation to hearing outcome. Permanent hearing loss not only disrupts acquisition of spoken language, but also affects other domains of neurocognitive development, and by this constitutes a particularly serious obstacle to optimal development and education. So far, several indicators are generally considered as a risk factor for hearing loss in childhood and listed as such in the 'principles and guidelines for early hearing detection and intervention programs' by the Joint Committee on Infant Hearing. ${ }^{1}$ However, other variables like chorioamnionitis and perinatal asphyxia are extensively studied because of their association with adverse perinatal outcome, but the significance of these factors in the onset of hearing loss is not clear and is the main focus of this thesis

In experimental animals, intrauterine inflammation can be produced by exposing the fetus to lipopolysaccharide (LPS), which is a product of the outer membrane of Gramnegative bacteria. In Chapter Two we report a review of the literature to elucidate the role of this toxin in congenital SNHL and to identify the pathogenesis and potential transmission routes. We speculate that different routes of exposure to LPS in utero can result in congenital inner ear damage.

To demonstrate the effects of an intrauterine infection by LPS to the auditory pathway, we introduce in Chapter Three a unique experimental model of chorioamnionitis in sheep. In this model, we demonstrate an inflammatory response in the fetal perilymph and deleterious effect to ABR parameters after birth by intrauterine LPS exposure compared to sham treatment. By this, we confirm the hypothesis of chorioamnionitis induced inflammatory effect to the fetal inner ear and functional impaired hearing outcomes after birth by an LPS induced-intrauterine infection.

We investigate the clinical relevance of a histological chorioamnionitis in neonatal hearing outcome in two Dutch cohorts of very preterm newborns in Chapter Four. In multivariable analyses, an abnormal neonatal hearing screening by automated auditory brainstem response (AABR) was not predicted by the presence of histological chorioamnionitis, either with or without fetal involvement. Significant predictors of abnormal AABR included e.g. birth weight, umbilical cord artery $\mathrm{pH}$ and mechanical ventilation.

In Chapter Five we focus on the auditory features of the postasphyxial syndrome in newborns and the effect of anesthetic drugs to attenuate secondary neuronal injury elicited by hypoxia-ischemia. After delivery preceded by in utero umibilical cord occlusion, changes to serial auditory brainstem responses were observed in the asphyxia group relative to the control group. Comparison of anesthetic treatment in the asphyxia group revealed a significantly lower elevation in threshold, and less impairment in the ABR amplitudes and latencies during propofol anesthesia as compared to isoflurane anesthesia. These 
results support the hypothesis that anesthesia with propofol has a preventive effect on the functional changes to the auditory pathway in the event of perinatal asphyxia.

In the study in Chapter Six we assess the feasibility of high-resolution MR imaging in evaluating the microstructures of the inner ear. We demonstrate in preterm ex vivo lambs high quality detailed images of the fluid filled structures of the labyrinth by 7T MR imaging. This tool may allow for the evaluation of subtle inner ear disorders and the effect of interventional therapies in experimental animal protocols in near future.

The studies included in this thesis were performed to improve our understanding of the perinatal risk factors for congenital hearing loss. Although the survival of preterm infants over the last decade has been improved by advances in perinatal care, the prevalence of major neonatal and long-term morbidities in this group has not significantly changed. A better insight into the factors related to adverse hearing outcome in childhood might help in designing potential otoprotective strategies in perinatal care. Keeping in mind that hearing impairment has major implications for quality of life, this can be of great socioeconomic value for the society in near future.

\section{Reference}

1. Year 2007 position statement: Principles and guidelines for early hearing detection and intervention programs (2007). Pediatrics 120 (4):898-921. 


I

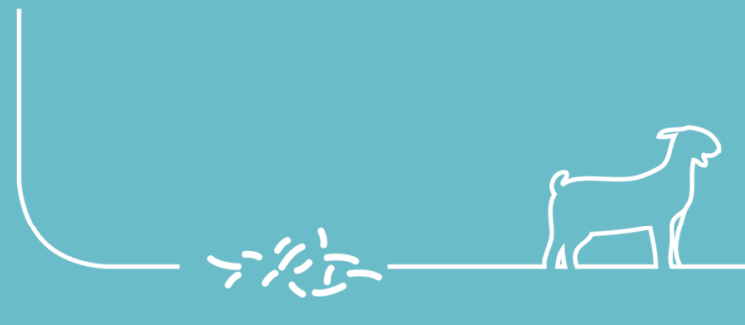

o wolh

Samenvatting 



\section{Samenvatting}

Dit proefschrift beschrijft aan aantal studies naar de perinatale risicofactoren voor gehoorverlies. Gehoorverlies in kinderen zorgt niet alleen voor een verstoring van de spraak- en taalontwikkeling, maar lijdt ook tot andere beperkingen in neurocognitieve ontwikkeling. Permanente gehoorschade vormt hiermee een belangrijke hindernis voor een optimale ontwikkeling en scholing. Door the Joint Committee on Infant Hearing zijn dusver meerdere risicofactoren voor gehoorverlies in kinderen aangewezen en opgenomen in 'principles and guidelines for early detection and intervention programs'. ${ }^{1}$ Echter, voor diverse andere variabelen zoals chorioamnionitis en perinatale asfyxie, die eerder van negatief voorspellende waarde zijn gebleken voor de algemene perinatale uitkomst, is de exacte invloed op het gehoor niet eenduidig. Dit vormt dan ook het onderwerp van studie van dit proefschrift.

Lipopolysaccharide (LPS) is een molecuul van de buiten membraan van Gramnegatieve bacteriën. Door foetale blootstelling aan dit toxine kan een intra-uteriene ontstekingsreactie worden veroorzaakt in experimentele dierstudies. In Hoofdstuk twee wordt een overzicht gegeven van de literatuur die de relatie tussen intra-uterien LPS en het gehoor beschrijft. Om de potentiële rol van dit toxine in het ontstaan van aangeboren perceptief gehoorverlies te belichten worden routes van transmissie en de pathogenese toegelicht.

De effecten van een LPS gemedieerde intra-uteriene infectie op het auditieve system wordt verder onderzocht in Hoofdstuk drie. Hiervoor introduceren wij een uniek chorioamnionitis diermodel gebruik makende van schapen. In dit model wordt aan de hand van analyse van de binnenoorvloeistof in foetale condities een ontstekingsreactie aangetoond ten gevolge van intra-uterien LPS blootstelling. Daarnaast worden functionele negatieve effecten gezien op het gehoor in de groep van LPS blootstelling ten opzichte van de controle groep door middel van BERA-onderzoek (Brainstem Evoked Response Audiometry / hersenstam-audiometrie). Hiermee kan worden bevestigd dat een LPS gemedieerde chorioamnionitis een foetale ontstekingsreactie kan geven van het labyrint en functionele effecten heeft op het gehoor na geboorte in dit model.

De klinische relevantie van deze bevindingen wordt geanalyseerd in Hoofdstuk vier. In een tweetal Nederlandse groepen van ernstig prematuur geboren kinderen wordt de relatie onderzocht tussen een histologisch bewezen chorioamnionitis en de uitkomsten van de neonatale screenende gehoortest. Hieruit blijkt een afwijkende gehoortest door middel van AABR techniek (Automated Auditory Brainstem Response) niet voorspeld te worden door de aanwezigheid van histologisch bewezen chorioamnionitis, al dan niet met foetale betrokkenheid. Significante voorspellers van een afwijkende gehoortest worden gevonden in o.a. het geboortegewicht, navelstreng $\mathrm{pH}$ en de noodzaak voor mechanische ventilatie. 
In Hoofdstuk vijf wordt de nadruk gelegd op het gevolg van perinatale asfyxie op het gehoor en de interventie door middel van anesthesiologische farmaca om secundaire neuronale schade te verminderen ten gevolge van hypoxie-ischemie. In het pasgeboren schaap wordt na een periode van intra-uteriene navelstreng occlusie veranderingen waargenomen van hersenstampotentialen ten opzichte van de controle groep. In de asfyxie groep wordt tijdens propofol anesthesie een kleinere verslechtering gezien van de gehoordrempel en BERA piek amplitudes en latentietijden in vergelijking met isofluraan anesthesie. Deze resultaten ondersteunen de hypothese dat anesthesie met propofol een beschermend effect heeft op functionele gehoorveranderingen ten gevolge van perinatale asfyxie.

Hoofdstuk zes beschrijft de haalbaarheid van de toepassing van hoge resolutie MRI in het analyseren van de microstructuren van het binnenoor. Door middel van ex vivo 7T MRI beeldvorming van het os temporale van prematuur geboren lammeren worden de met vloeistof gevulde structuren van het labyrint in detail in beeld gebracht. De toepassing van deze techniek zou kunnen worden toegepast in de toekomst om subtiele veranderingen van het binnenoor te kunnen detecteren en kan van waarde zijn in de beoordeling van effecten van diverse effecten in experimentele diermodellen.

De in dit proefschrift beschreven studies zijn uitgevoerd om het begrip van perinatale risico factoren voor aangeboren gehoorverlies te vergroten. Hoewel door verbeteringen in de perinatale zorg de overleving van prematuur geboren kinderen is toegenomen gedurende de laatste tientallen jaren, is de prevalentie van morbiditeit op de korte en langer termijn niet evident veranderd in deze groep. Een beter begrip van factoren die kunnen lijden tot een negatieve gehooruitkomst in kinderen kan uiteindelijk bijdragen in de ontwikkeling van beschermende perinatale maatregelen gericht op gehooruitkomst .In ogenschouw nemende dat gehoorverlies grote gevolgen heeft op de kwaliteit van leven, kan dit inzicht van grote sociaal-economische waarde zijn voor de maatschappij in de toekomst.

\section{Referentie}

1. Year 2007 position statement: Principles and guidelines for early hearing detection and intervention programs (2007). Pediatrics 120 (4):898-921. 